\title{
The effect of herbicides on the yield structure elements and the productivity of oil flax
}

\author{
Alexander S. Bushnev ${ }^{1 *}$, Gennady I. Orekhov ${ }^{1}$, Sergei P. Podlesny ${ }^{1}$ and Yulia V. Mamyrko ${ }^{1}$ \\ ${ }^{1}$ V.S. Pustovoit All-Russian Research Institute of Oil Crops, 17, Filatova Str., Krasnodar, 350038, Russia
}

\begin{abstract}
The article provides the research results concerning the effect of antidicotyledonous herbicide Sekator Turbo, OD (a.i. amidosulfuron + iodosulfuron-methyl-sodium + mefenpyr-diethyl) in a tank mixture with various graminicides Quickstep, FEM (a.i. clethodim + haloxyfop-P-methyl), Bagheera, EC (a.i. quizalofop-P-tefuryl), Fuzilad Forte, EC (a.i. fluazifop-P-butyl), Miura, EC (a.i. quizalofop-P-ethyl), and Zellek-super, EC (a.i. haloxyfop-P-methyl) on the yield structure elements and the productivity of lowlinolenic (Nilin) and linolenic (FLIZ) varieties of oil flax on leached chernozem of the Western Ciscaucasia. We have found that the treatment of sowings with herbicides did not have a significant effect on the yield structure elements (thousand-seed weight and bulk weight of seeds). The treatment of sowings of the variety Nilin with the composition of Sekator Turbo + Bagheera or Sekator Turbo + Miura, and the variety FLIZ with Sekator Turbo + Bagheera, Sekator Turbo + Quickstep, Sekator Turbo + Fuzilad Forte, Sekator Turbo + Miura contributes to the receiving of oil flax yield at the level of the control with manual weeding. Tank mixtures of Sekator Turbo + Bagheera, Sekator Turbo + Miura decreased the oil content of seeds of the variety Nilin by $0.5 \%$. The application of herbicides Sekator Turbo, OD $(0.1 \mathrm{l} / \mathrm{ha})+$ Bagheera, EC ( $1.5 \mathrm{l} / \mathrm{ha}$ ) provided the highest oil yield of the variety Nilin $-0.34 \mathrm{t} / \mathrm{ha}$, and of the variety FLIZ $-0.54 \mathrm{t} / \mathrm{ha}$. The composition of Sekator Turbo + Zellek-super led to a significant decrease in the productivity and oil content of seeds of the variety FLIZ - by $0.15 \mathrm{t} / \mathrm{ha}$ and $0.6 \%$, respectively.
\end{abstract}

\section{Introduction}

The introduction of oil flax into Russian agricultural production happened relatively recently, but the rate of its spreading in the country's regions is remarkably high. From 2001 to 2020, the crop acreage of oil flax increased by more than 118 times - from 8.7 to 1030.5 thousand hectares. Several factors contribute to it, one of which is the high marginality of the crop. According to the Institute for Agricultural market studies (IKAR), the quotes of world prices for flax seeds for the $2020 / 2021$ season increased by $35 \%$, purchase prices in Russia - by $85-90 \%$.

However, the growth of gross output of oil flax is limited by low yields, which in 2020 did not exceed $0.81 \mathrm{t} / \mathrm{ha}$ on average in the country, and $1.3 \mathrm{t} / \mathrm{ha}$ in the Krasnodar region, amounting to $32-65 \%$ of the potential crop productivity that exceeds $2.0-2.5 \mathrm{t} / \mathrm{ha}$ and more. The success in attaining high productivity is largely related to the experience in cultivation and the absence of violations of the oil flax cultivation technology, having specific features, one of which is the low competitiveness of the crop against weeds, the yield losses from which can reach more than $30-50 \%$. As a result, the role of crop protective measures against weeds increases significantly in the cultivation technology.

K. Pudełko, J. Mańkowski, and J. Kołodziej note that the application of herbicides resulted in a double decrease in the number and weight of weeds in flax sowings [1]. The studies of S. Andruszczak, U. GawlikDziki, P. Kraska, E. Kwiecińska-Poppe, K. Różyło, and E. Pałys showed that the use of herbicidal treatments promoted an increase in the productivity of oil flax by 1.8-2 times [2]. According to M.E. Kurtenbach, E.N. Johnson, R.H. Gulden, S. Duguid, M. Dyck, and C.J. Willenborg, the use of chemical weed control led to the increase in flax productivity more than $600 \mathrm{~kg} / \mathrm{ha}$ [3].

A large biological diversity of weeds in flax sowings defines the crop protection requirement to give preference to tank mixtures of herbicides with different active ingredients, which ensure the destruction of both gramineous and broad-leaved weeds. However, in practice, there are frequent cases of phytotoxic action of some tank mixtures of herbicides on cultivated plants, contributing to a decrease in the thousand-seed weight, productivity, and oil content of seeds, and leading to a shortage of oil yield per unit of sowing area [4-7]. For example, flax showed tolerance to the herbicide combinations based on flutiacet-methyl, pyroxasulfone, and topramezone, but the mixtures of flutiacet-methyl and topramezone with MCPA and bromoxynil had a negative effect on the crop [8]. In the conditions of the south of Russia, the application of the tank mixture of herbicides with the active ingredients clopyralid and quizalofop-P-ethyl contributed to obtaining high productivity indicators of oil flax. At the same time, the

Corresponding author: vniimk-agro@ mail.ru 
use of combination of preparations based on thifensulfuron-methyl or metsulfuron-methyl with a herbicide with the active ingredient quizalofop-P-ethyl results in a decrease in the productivity and oil content of seeds of the crop $[9,10]$. In the Republic of Belarus, the composite formulations including herbicides Callisto (a.i. mesotrione), Sekator Turbo (a.i. amidosulfuron + iodosulfuron-methyl sodium + mefenpyr-diethyl) and Miura (a.i. quizalofop-P-ethyl) provided a positive tendency to an increase in the thousand-seed weight and a significant increase in productivity of $0.84-1.36 \mathrm{t} / \mathrm{ha}$ (with the control productivity of $0.32 \mathrm{t} / \mathrm{ha}$ ), but at the same time slightly decreased the oil content of seeds [11].

The aim of the research is to study the effect of tank mixtures of herbicides on the yield structure elements and productivity of various varieties of oil flax on leached chernozem of the Western Ciscaucasia.

\section{Materials and methods}

We carried out the research on the fields of V.S. Pustovoit All-Russian Research Institute of Oil Crops (Russia, Krasnodar) in a zone of unstable moistening in the south of Russia during the oil flax cultivation in 2018-2020. The soil of the experimental plots was leached chernozem, low-humic, extra-heavy, heavy-loamy. The objects of the research were the oil flax varieties: a low-linolenic Nilin (with a linolenic acid content up to $35 \%$ ) and mid-linolenic FLIZ (with a linolenic acid content of 36-49\%).

The oil flax variety Nilin is relatively tall, the average plant height is $75-85 \mathrm{~cm}$, the growth period is 85-90 days, it has a potential productivity of 1.9-2.1 t/ha with an oil content in seeds of $45.0-45.6 \%$, the thousand-seed weight is $5.1-5.3 \mathrm{~g}$. Due to the low content of linolenic acid in the oil (2.8-15.2\%), the oil is suitable for food purposes.

The oil flax variety FLIZ has a high potential productivity of 2.5-2.7 t/ha, the growth season is $85-87$ days, the average plant height is $68-73 \mathrm{~cm}$, the thousand-seed weight is within 7.8-8.0 g. The seed oil of this flax variety, due to high content of linolenic acid in it (41.2-43.6\%), is used for technical purposes, in medicine and perfumery.

We studied the methods of weed control in the sowings of Linum usitatisimum L. with tank mixtures of the antidicotyledonous herbicide Sekator Turbo, OD (active ingredients amidosulfuron + iodosulfuron-methyl sodium + mefenpyr-diethyl) with one of the graminicides Quickstep, FEM (active ingredients clethodim + haloxyfop-P-methyl), Bagheera, EC (active ingredient quizalofop-P-tefuryl), Fuzilad Forte, EC (active ingredient fluazifop-P-butyl), Miura, EC (active ingredient quizalofop-P-ethyl), Zellek-super, EC (active ingredient haloxyfop-P-methyl).

The experimental design included:

1. Control, manual weeding;

And tank mixtures of herbicides:

2. Sekator Turbo, OD (0.1 1/ha) + Bagheera, EC (1.5 1/ha);
3. Sekator Turbo, OD (0.1 1/ha) + Fuzilad Forte, EC (1.0 l/ha);

4. Sekator Turbo, OD (0.1 1/ha) + Quickstep, FEM (0.8 1/ha);

5. Sekator Turbo, OD (0.1 1/ha) + Miura, EC (1.2 1/ha);

6. Sekator Turbo, OD (0.1 1/ha) + Zellek-super, EC (1.0 1/ha).

The herbicides Sekator Turbo, Quickstep, and Miura are regulated for application on oil flax, while Bagheera, Zellek-super, and Fuzilad Forte - on fiber flax, and are included in The State Catalog of Pesticides and Agrochemicals Approved for Use in the Russian Federation. We applied tank mixtures at the stage of true leaves development of oil flax with a working fluid rate of $300 \mathrm{l} / \mathrm{ha}$. The area of the recording plot was $12 \mathrm{~m}^{2}$ with four replications. We harvested the yield by direct combining and normalized the seeds to $100 \%$ of purity and $12 \%$ of moisture content. We determined the oil content of seeds by the method of nuclear magnetic resonance in accordance with State Standard GOST R 8.620-2006.

\section{Results and discussion}

The nature of the precipitation distribution during the growth season and the average daily air temperature during a stage of flowering-filling of seeds determines a high and quality yield of oil flax. In 2018 and 2019, the amount of precipitation in the pre-sowing period was sufficient for the development of good moisture reserves in the soil: 472.9 and $352.5 \mathrm{~mm}$, respectively. During these years, the precipitation during the growth season of oil flax was distributed unevenly: its amount significantly exceeded the level of annual average values in May and July and was lower in April and June. The rise of air temperature over the long-term annual average values in April and July was relatively small $\left(0.1-3.1^{\circ} \mathrm{C}\right)$, and during the budding and flowering stage (in May and June) reached $5.0^{\circ} \mathrm{C}$ (Fig. 1), which could negatively affect the crop productivity.

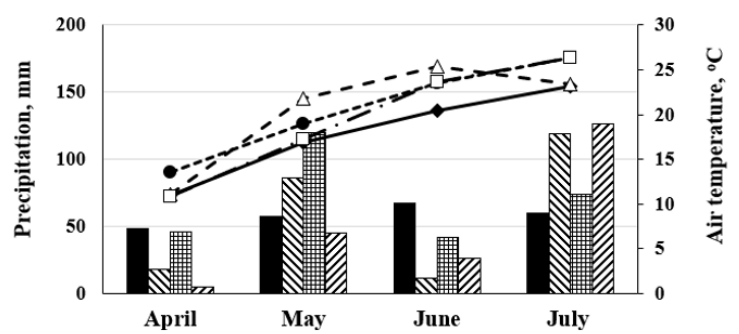

- Average long-term precipitation $\rightarrow$-Average long-term air temperature S Precipitation in 2018 田Precipitation in 2019 $\triangle$ Precipitation in 2020

-๑- Air temperature in 2018

$-\triangle$ Air temperature in 2019

$\neg \cdot$ Air temperature in 2020

Fig. 1. Weather conditions during the research period (weather station of V.S. Pustovoit All-Russian Research Institute of Oil Crops, 2018-2020)

In 2020, the vegetation of oil flax took place under the risk of hydrothermal stress, when, at an increased by 0.4-3.2 ${ }^{\circ} \mathrm{C}$ temperature, the initial reserve of soil moisture was only $59.5 \%$, and the amount of 
precipitation during the growth season was $86.6 \%$ of annual average values.

Therefore, the weather conditions of 2018 and 2019 can be considered moderately favorable, and of 2020 unfavorable for the crop cultivation.

The weeds in the agrophytocenosis were mainly represented by dicotyledonous plants (Solanum nigrum L., Abutilon theophrasti Medicus, Amaranthus retroflexus L., Xanthium strumarium L., Chenopodium album L., Convolvulys arvensis L., Sonchus arvensis L.) with the presence of monocotyledonous (Setaria glauca L.) ones. The biological effectiveness of the herbicide tank mixtures was in the range of 32.4-79.7 \%. On average, over three years, we recorded the maximum effect in the variant with the use of the tank mixture of Sekator Turbo + Bagheera - 66.7\%, the minimum Sekator Turbo + Quickstep - $41.6 \%$ (Table 1).

Table 1. The biological effectiveness of tank mixtures of the herbicides, on average for 2018-2020

\begin{tabular}{|c|c|c|c|}
\hline \multirow{2}{*}{ Variant } & \multicolumn{3}{|c|}{ Biological effectiveness*, \% } \\
\cline { 2 - 4 } & $\begin{array}{c}\text { variety } \\
\text { Nilin }\end{array}$ & $\begin{array}{c}\text { variety } \\
\text { FLIZ }\end{array}$ & average \\
\hline $\begin{array}{c}\text { Sekator Turbo, OD (0.1 1/ha) } \\
\text { + Bagheera, EC (1.5 1/ha) }\end{array}$ & 79.7 & 53.7 & 66.7 \\
\hline $\begin{array}{c}\text { Sekator Turbo, OD (0.1 1/ha) } \\
\text { + Fuzilad Forte, EC (1.0 1/ha) }\end{array}$ & 53.8 & 60.2 & 57.0 \\
\hline $\begin{array}{c}\text { Sekator Turbo, OD (0.1 1/ha) } \\
\text { + Quickstep, FEM (0.8 1/ha) }\end{array}$ & 50.7 & 32.4 & 41.6 \\
\hline $\begin{array}{c}\text { Sekator Turbo, OD (0.1 1/ha) } \\
\text { + Miura, EC (1.2 1/ha) }\end{array}$ & 61.6 & 50.9 & 56.3 \\
\hline $\begin{array}{c}\text { Sekator Turbo, OD (0.1 1/ha) } \\
\text { + Zellek-super, EC (1.0 1/ha) }\end{array}$ & 49.1 & 43.5 & 46.3 \\
\hline
\end{tabular}

*- in 40-60 days after the herbicide treatment

The variety Nilin is characterized by a high initial rate of growth and growth of green matter; at the flowering stage, its plant height was $10-15 \mathrm{~cm}$ higher than of the variety FLIZ. We considered this fact caused a certain rise of the biological effectiveness in several variants with this variety, since the available higher projective cover provides a better competitiveness of sowings to weeds.

The analysis of such elements of yield structure as the thousand-seed weight and the bulk weight of seeds formed the basis for a comprehensive evaluation of the degree of effect of chemical protection agents on oil flax plants.

The carried out research helped to establish that tank mixtures of the herbicides did not have a significant effect on the thousand-seed weight, which was in the range of 4.6-4.8 $\mathrm{g}$ for the variety Nilin, and 6.6-6.9 $\mathrm{g}$ for the variety FLIZ (Table 2).

The bulk weight of flax seeds of the variety Nilin varied by variants within $687.9-705.2 \mathrm{~g} / \mathrm{l}$, of the variety FLIZ - 692.3.0-699.7 g/l (Table 3). We received the highest values of the bulk weight of seeds for both varieties of oil flax in the control with manual weeding and in the variant with the tank mixture of Sekator Turbo + Fuzilad Forte, however, the differences between the variants of the experiment were insignificant.
Table 2. The effect of various tank mixtures of the herbicides on the thousand-seed weight of oil flax varieties

\begin{tabular}{|l|c|c|}
\hline \multirow{2}{*}{ Variant } & \multicolumn{2}{|c|}{$\begin{array}{c}\text { Thousand-seed weight } \\
\text { in 2018-2020, g }\end{array}$} \\
\cline { 2 - 3 } variety Nilin \\
\hline \multicolumn{2}{|c|}{ min-max } & average \\
\hline Control, manual weeding & $4.3-5.3$ & 4.7 \\
\hline $\begin{array}{l}\text { Sekator Turbo, OD (0.1 1/ha) + } \\
\text { Bagheera, EC (1.5 1/ha) }\end{array}$ & $4.2-5.3$ & 4.7 \\
\hline $\begin{array}{l}\text { Sekator Turbo, OD (0.1 1/ha) }+ \\
\text { Fuzilad Forte, EC (1.0 1/ha) }\end{array}$ & $4.5-5.3$ & 4.8 \\
\hline $\begin{array}{l}\text { Sekator Turbo, OD (0.1 1/ha) }+ \\
\text { Quickstep, FEM (0.8 1/ha) }\end{array}$ & $4.3-5.5$ & 4.8 \\
\hline $\begin{array}{l}\text { Sekator Turbo, OD (0.1 1/ha) + } \\
\text { Miura, EC (1.2 1/ha) }\end{array}$ & $4.3-5.2$ & 4.6 \\
\hline $\begin{array}{l}\text { Sekator Turbo, OD (0.1 1/ha) + } \\
\text { Zellek-super, EC (1.0 1/ha) }\end{array}$ & $4.3-5.2$ & 4.7 \\
\hline HMD05 & 0.23 \\
\hline \multicolumn{2}{|c|}{ variety FLIZ } & 6.8 \\
\hline Control, manual weeding & $6.4-7.7$ & 6.6 \\
\hline $\begin{array}{l}\text { Sekator Turbo, OD (0.1 1/ha) + } \\
\text { Bagheera, EC (1.5 1/ha) }\end{array}$ & $6.2-7.3$ & 6.25 \\
\hline $\begin{array}{l}\text { Sekator Turbo, OD (0.1 1/ha) + } \\
\text { Fuzilad Forte, EC (1.0 1/ha) }\end{array}$ & $6.1-7.6$ & 6.6 \\
\hline $\begin{array}{l}\text { Sekator Turbo, OD (0.1 1/ha) + } \\
\text { Quickstep, FEM (0.8 1/ha) }\end{array}$ & $6.2-7.5$ & 6.6 \\
\hline $\begin{array}{l}\text { Sekator Turbo, OD (0.1 1/ha) + } \\
\text { Miura, EC (1.2 1/ha) }\end{array}$ & $6.2-7.7$ & 6.9 \\
\hline $\begin{array}{l}\text { Sekator Turbo, OD (0.1 1/ha) + } \\
\text { Zellek-super, EC (1.0 1/ha) }\end{array}$ & $6.2-7.5$ & 6.7 \\
\hline HMD05 & \\
\hline
\end{tabular}

Table 3. The effect of various tank mixtures of the herbicides on the bulk weight of seeds of oil flax varieties

\begin{tabular}{|c|c|c|}
\hline \multirow[t]{2}{*}{ Variant } & \multicolumn{2}{|c|}{$\begin{array}{c}\text { Bulk weight of seeds in } \\
2018-2020, \mathrm{~g} / \mathrm{l}\end{array}$} \\
\hline & $\min -\max$ & average \\
\hline \multicolumn{3}{|c|}{ variety Nilin } \\
\hline Control, manual weeding & $678.7-707.1$ & 705.2 \\
\hline $\begin{array}{l}\text { Sekator Turbo, OD (0.1 1/ha) } \\
\text { + Bagheera, EC (1.5 l/ha) }\end{array}$ & $674.6-715.7$ & 694.7 \\
\hline $\begin{array}{l}\text { Sekator Turbo, OD (0.1 l/ha) } \\
+ \text { Fuzilad Forte, EC (1.0 1/ha) }\end{array}$ & $679.6-716.7$ & 699.5 \\
\hline $\begin{array}{l}\text { Sekator Turbo, OD (0.1 1/ha) } \\
\text { + Quickstep, FEM (0.8 1/ha) }\end{array}$ & $674.8-707.6$ & 687.9 \\
\hline $\begin{array}{l}\text { Sekator Turbo, OD (0.1 l/ha) } \\
+ \text { Miura, EC (1.2 1/ha) }\end{array}$ & $676.5-723.3$ & 696.0 \\
\hline $\begin{array}{l}\text { Sekator Turbo, OD (0.1 l/ha) } \\
\text { + Zellek-super, EC (1.0 1/ha) }\end{array}$ & $687.2-717.9$ & 698.6 \\
\hline \multicolumn{2}{|l|}{ HMD $_{05}$} & 8.6 \\
\hline \multicolumn{3}{|c|}{ variety FLIZ } \\
\hline Control, manual weeding & $682.4-715.0$ & 698.1 \\
\hline $\begin{array}{l}\text { Sekator Turbo, OD (0.1 1/ha) } \\
\text { + Bagheera, EC (1.5 1/ha) }\end{array}$ & $673.8-710.3$ & 694.0 \\
\hline $\begin{array}{l}\text { Sekator Turbo, OD (0.1 l/ha) } \\
+ \text { Fuzilad Forte, EC (1.0 1/ha) }\end{array}$ & $693.2-711.6$ & 699.7 \\
\hline $\begin{array}{l}\text { Sekator Turbo, OD (0.1 1/ha) } \\
\text { + Quickstep, FEM }(0.8 \text { 1/ha) }\end{array}$ & $664.3-713.8$ & 692.3 \\
\hline $\begin{array}{l}\text { Sekator Turbo, OD (0.1 l/ha) } \\
\text { + Miura, EC (1.2 1/ha) }\end{array}$ & $692.0-708.1$ & 698.6 \\
\hline $\begin{array}{l}\text { Sekator Turbo, OD }(0.1 \mathrm{l} / \mathrm{ha}) \\
+ \text { Zellek-super, EC }(1.0 \mathrm{l} / \mathrm{ha}) \\
\end{array}$ & $671.0-714.8$ & 697.7 \\
\hline \multicolumn{2}{|l|}{ HMD 05} & 9.3 \\
\hline
\end{tabular}


We received the maximum yield of the oil flax variety Nilin on average for three years of the research in the control with manual weeding - $0.99 \mathrm{t} / \mathrm{ha}$. In all variants with chemical protection against weeds the yield was slightly lower; we recorded the values closer to the control in the variants with application of Sekator Turbo + Bagheera (0.95 t/ha) and Sekator Turbo + Miura (0.93 t/ha) (Table 4). We received the lowest yield under treatment of sowings with the tank mixture of Sekator Turbo + Zellek-super $-0.88 \mathrm{t} / \mathrm{ha}$.

The tank mixture of Sekator Turbo + Bagheera was good for the sowings of the oil flax variety FLIZ, it contributed to an increase in yield by $0.05 \mathrm{t} / \mathrm{ha}$ compared to the control. We observed the high effectiveness in variants with Sekator Turbo + Quickstep, where the average yield was at the level of the control with manual weeding $-1.29 \mathrm{t} / \mathrm{ha}$.

In relatively favorable weather conditions of 2018 and 2019, we received the high productivity of the variety FLIZ under application of the tank mixture of Sekator Turbo + Miura, however, in arid 2020, this mixture negatively affected the sowings, reducing the yield to $1.14 \mathrm{t} / \mathrm{ha}$.

On average for three years, we received the lowest yield of the oil flax variety FLIZ $-1.14 \mathrm{t} / \mathrm{ha}$, in the variant with application of the tank mixture of Sekator Turbo + Zellek-super due to the phytotoxic effect on cultivated plants. In this variant, we noted a significant maximum decrease in yield by $0.15 \mathrm{t} / \mathrm{ha}$ in comparison with the control with manual weeding.

Table 4. The productivity of oil flax varieties under application of various tank mixtures of the herbicides

\begin{tabular}{|c|c|c|}
\hline \multirow[t]{2}{*}{ Variant } & \multicolumn{2}{|c|}{$\begin{array}{l}\text { Productivity in } \\
\text { 2018-2020, } \mathrm{t} / \mathrm{ha}\end{array}$} \\
\hline & $\min -\max$ & average \\
\hline \multicolumn{3}{|c|}{ variety Nilin } \\
\hline Control, manual weeding & $0.84-1.14$ & 0.99 \\
\hline $\begin{array}{c}\text { Sekator Turbo, OD (0.1 1/ha) + } \\
\text { Bagheera, EC (1.5 1/ha) }\end{array}$ & $0.84-1.06$ & 0.95 \\
\hline $\begin{array}{l}\text { Sekator Turbo, OD }(0.1 \text { 1/ha })+ \\
\text { Fuzilad Forte, EC (1.0 1/ha) }\end{array}$ & $0.71-1.08$ & 0.91 \\
\hline $\begin{array}{c}\text { Sekator Turbo, OD }(0.1 \text { 1/ha })+ \\
\text { Quickstep, FEM }(0.8 \text { 1/ha })\end{array}$ & $0.83-0.96$ & 0.89 \\
\hline $\begin{array}{c}\text { Sekator Turbo, OD }(0.1 \mathrm{l} / \mathrm{ha})+ \\
\text { Miura, EC }(1.2 \mathrm{l} / \mathrm{ha})\end{array}$ & $0.79-1.06$ & 0.93 \\
\hline $\begin{array}{c}\text { Sekator Turbo, OD }(0.1 \mathrm{l} / \mathrm{ha})+ \\
\text { Zellek-super, EC }(1.0 \mathrm{l} / \mathrm{ha})\end{array}$ & $0.85-0.90$ & 0.88 \\
\hline \multicolumn{2}{|l|}{$\mathrm{HMD}_{05}$} & 0.14 \\
\hline \multicolumn{3}{|c|}{ variety FLIZ } \\
\hline Control, manual weeding & $1.22-1.35$ & 1.29 \\
\hline $\begin{array}{c}\text { Sekator Turbo, OD (0.1 l/ha) + } \\
\text { Bagheera, EC (1.5 l/ha) } \\
\end{array}$ & $1.20-1.42$ & 1.34 \\
\hline $\begin{array}{l}\text { Sekator Turbo, OD }(0.1 \text { 1/ha })+ \\
\text { Fuzilad Forte, EC (1.0 1/ha) }\end{array}$ & $1.18-1.35$ & 1.25 \\
\hline $\begin{array}{c}\text { Sekator Turbo, OD }(0.1 \text { 1/ha })+ \\
\text { Quickstep, FEM }(0.8 \text { 1/ha })\end{array}$ & $1.22-1.39$ & 1.29 \\
\hline $\begin{array}{c}\text { Sekator Turbo, OD }(0.1 \text { 1/ha })+ \\
\text { Miura, EC (1.2 1/ha) }\end{array}$ & $1.14-1.44$ & 1.27 \\
\hline $\begin{array}{c}\text { Sekator Turbo, OD }(0.1 \text { 1/ha })+ \\
\text { Zellek-super, EC (1.0 l/ha) }\end{array}$ & $1.13-1.15$ & 1.14 \\
\hline \multicolumn{2}{|l|}{$\mathrm{HMD}_{05}$} & 0.11 \\
\hline
\end{tabular}

The tank mixtures of the herbicides affected differently the oil content in seeds of various flax varieties. For example, for the variety Nilin, on average over three years, in the variants with Sekator Turbo + Bagheera, Sekator Turbo + Miura and Sekator Turbo + Zellek-super it was significantly (by $0.5-0.6 \%$ ) lower than in the control with manual weeding (Table 5). We noted the lowest value when using Sekator Turbo + Zellek-super $-41.0 \%$.

Oil content in seeds of the variety FLIZ in variants with Sekator Turbo + Bagheera, Sekator Turbo + Quickstep and Sekator Turbo + Miura was at the level of the control with manual weeding (45.6\%): 45.4, 45.5 and $45.4 \%$, respectively. We noted a significant decrease accompanying the application of Sekator Turbo + Fuzilad Forte - by $0.5 \%$ and Sekator Turbo + Zelleksuper - by $0.6 \%$.

The largest oil yield of crop was provided by manual weeding of sowings and the application of the mixture of the herbicides Sekator Turbo + Bagheera, amounting to 0.36 and $0.34 \mathrm{t} /$ ha for the variety Nilin, and 0.52 and $0.54 \mathrm{t} / \mathrm{ha}$ for the variety FLIZ, respectively (Table 6). The oil yield was slightly lower under application of the tank mixtures of Sekator Turbo + Fuzilad Forte, Sekator Turbo + Quickstep and Sekator Turbo + Miura. The negative effect of the herbicide composition of Sekator Turbo + Zellek-super on the crop led to a significant decrease in oil yield in comparison with the control with manual weeding, amounting to $0.31 \mathrm{t} / \mathrm{ha}$ for the variety Nilin and $0.45 \mathrm{t} /$ ha for the variety FLIZ.

Table 5. Oil content of seeds of oil flax varieties under application of the various tank mixtures of the herbicides

\begin{tabular}{|c|c|c|}
\hline \multirow[t]{2}{*}{ Variant } & \multicolumn{2}{|c|}{$\begin{array}{l}\text { Oil content of seeds in } \\
2018-2020, \%\end{array}$} \\
\hline & $\min -\max$ & average \\
\hline \multicolumn{3}{|c|}{ variety Nilin } \\
\hline Control, manual weeding & $40.9-42.1$ & 41.6 \\
\hline $\begin{array}{c}\text { Sekator Turbo, OD (0.1 l/ha) + } \\
\text { Bagheera, EC (1.5 l/ha) }\end{array}$ & $40.6-41.8$ & 41.1 \\
\hline $\begin{array}{l}\text { Sekator Turbo, OD }(0.1 \text { l/ha })+ \\
\text { Fuzilad Forte, EC (1.0 l/ha) }\end{array}$ & $40.7-42.1$ & 41.2 \\
\hline $\begin{array}{c}\text { Sekator Turbo, OD }(0.1 \text { l/ha })+ \\
\text { Quickstep, FEM }(0.8 \text { l/ha })\end{array}$ & $40.5-42.1$ & 41.2 \\
\hline $\begin{array}{c}\text { Sekator Turbo, OD }(0.1 \mathrm{l} / \mathrm{ha})+ \\
\text { Miura, EC }(1.2 \mathrm{l} / \mathrm{ha})\end{array}$ & $40.6-41.7$ & 41.1 \\
\hline $\begin{array}{c}\text { Sekator Turbo, OD (0.1 l/ha) + } \\
\text { Zellek-super, EC (1.0 l/ha) }\end{array}$ & $40.2-41.7$ & 41.0 \\
\hline \multicolumn{2}{|l|}{$\mathrm{HMD}_{05}$} & 0.41 \\
\hline \multicolumn{3}{|c|}{ variety FLIZ } \\
\hline Control, manual weeding & $45.1-45.9$ & 45.6 \\
\hline $\begin{array}{c}\text { Sekator Turbo, OD }(0.1 \mathrm{l} / \mathrm{ha})+ \\
\text { Bagheera, EC }(1.5 \mathrm{l} / \mathrm{ha})\end{array}$ & $45.3-45.6$ & 45.4 \\
\hline $\begin{array}{l}\text { Sekator Turbo, OD (0.1 1/ha) + } \\
\text { Fuzilad Forte, EC (1.0 1/ha) }\end{array}$ & $44.9-45.6$ & 45.1 \\
\hline $\begin{array}{c}\text { Sekator Turbo, OD }(0.1 \text { l/ha })+ \\
\text { Quickstep, FEM }(0.8 \text { l/ha })\end{array}$ & $45.0-45.7$ & 45.5 \\
\hline $\begin{array}{c}\text { Sekator Turbo, OD (0.1 l/ha) + } \\
\text { Miura, EC (1.2 1/ha) }\end{array}$ & $45.0-45.7$ & 45.4 \\
\hline $\begin{array}{c}\text { Sekator Turbo, OD (0.1 l/ha) + } \\
\text { Zellek-super, EC (1.0 1/ha) } \\
\end{array}$ & $44.3-45.6$ & 45.0 \\
\hline \multicolumn{2}{|l|}{$\mathrm{HMD}_{05}$} & 0.41 \\
\hline
\end{tabular}


Table 6. The effect of the composition of tank mixtures of the herbicides on the oil yield of oil flax varieties

\begin{tabular}{|c|c|c|}
\hline \multirow[t]{2}{*}{ Variant } & \multicolumn{2}{|c|}{$\begin{array}{c}\text { Oil yield in 2018-2020, } \\
\text { t/ha }\end{array}$} \\
\hline & min-max & average \\
\hline \multicolumn{3}{|c|}{ variety Nilin } \\
\hline Control, manual weeding & $0.30-0.37$ & 0.36 \\
\hline $\begin{array}{c}\text { Sekator Turbo, OD }(0.1 \mathrm{l} / \mathrm{ha})+ \\
\text { Bagheera, EC (1.5 1/ha) }\end{array}$ & $0.30-0.38$ & 0.34 \\
\hline $\begin{array}{l}\text { Sekator Turbo, OD }(0.1 \text { 1/ha })+ \\
\text { Fuzilad Forte, EC (1.0 1/ha) } \\
\end{array}$ & $0.25-0.40$ & 0.33 \\
\hline $\begin{array}{c}\text { Sekator Turbo, OD }(0.1 \text { l/ha })+ \\
\text { Quickstep, FEM }(0.8 \text { l/ha })\end{array}$ & $0.30-0.35$ & 0.33 \\
\hline $\begin{array}{c}\text { Sekator Turbo, OD }(0.1 \text { 1/ha })+ \\
\text { Miura, EC (1.2 1/ha) }\end{array}$ & $0.28-0.38$ & 0.33 \\
\hline $\begin{array}{l}\text { Sekator Turbo, OD (0.1 l/ha) + } \\
\text { Zellek-super, EC (1.0 l/ha) }\end{array}$ & $0.30-0.32$ & 0.31 \\
\hline \multicolumn{2}{|l|}{ HMD05 } & 0.05 \\
\hline \multicolumn{3}{|c|}{ variety FLIZ } \\
\hline Control, manual weeding & $0.49-0.54$ & 0.52 \\
\hline $\begin{array}{c}\text { Sekator Turbo, OD }(0.1 \text { l/ha })+ \\
\text { Bagheera, EC }(1.5 \text { l/ha })\end{array}$ & $0.48-0.57$ & 0.54 \\
\hline $\begin{array}{l}\text { Sekator Turbo, OD }(0.1 \text { 1/ha })+ \\
\text { Fuzilad Forte, EC }(1.0 \text { l/ha })\end{array}$ & $0.47-0.53$ & 0.49 \\
\hline $\begin{array}{c}\text { Sekator Turbo, OD }(0.1 \text { 1/ha })+ \\
\text { Quickstep, FEM }(0.8 \text { 1/ha })\end{array}$ & $0.49-0.55$ & 0.51 \\
\hline $\begin{array}{c}\text { Sekator Turbo, OD }(0.1 \text { 1/ha })+ \\
\text { Miura, EC (1.2 1/ha) }\end{array}$ & $0.46-0.57$ & 0.51 \\
\hline $\begin{array}{l}\text { Sekator Turbo, OD (0.1 1/ha) + } \\
\text { Zellek-super, EC (1.0 l/ha) }\end{array}$ & $0.45-0.45$ & 0.45 \\
\hline \multicolumn{2}{|l|}{$\mathrm{HMD}_{05}$} & 0.04 \\
\hline
\end{tabular}

\section{Conclusion}

The research carried out in 2018-2020 have shown that on leached chernozem of the Western Ciscaucasia, the application of the tank mixtures of the herbicides Sekator Turbo, OD (0.1 1/ha) + Bagheera, EC (1.5 1/ha), Sekator Turbo, OD (0.1 1/ha) + Fuzilad Forte, EC (1.0 1/ha), Sekator Turbo, OD (0.1 1/ha) + Quickstep, FEM (0.8 1/ha), Sekator Turbo, OD (0.1 1/ha) + Miura, EC (1.2 1/ha) and Sekator Turbo, OD (0.1 1/ha) + Zelleksuper, EC (1.0 1/ha) on the low-linolenic (Nilin) and linolenic (FLIZ) types of oil flax varieties contributed to decrease in the number of weeds. The highest biological effectiveness was shown by the tank mixture of Sekator Turbo, OD (0.1 1/ha) + Bagheera, EC (1.5 1/ha) - 66.7\%, the lowest - by Sekator Turbo, OD (0.1 1/ha) + Quickstep, FEM (0.8 1/ha) - $41.6 \%$. The applied herbicides did not have a significant effect on the thousand-seed weight of oil flax, which was within 4.6-4.8 $\mathrm{g}$ for the variety Nilin and 6.6-6.9 $\mathrm{g}$ for the variety FLIZ. We did not observe the effect of the tank mixtures of herbicides on the bulk weight of seeds of oil flax varieties. We received the highest productivity of the flax variety Nilin under application of the tank mixtures of Sekator Turbo, OD (0.1 1/ha) + Bagheera, EC (1.5 1/ha) and Sekator Turbo, OD (0.1 1/ha) + Miura, EC (1.2 1/ha) - 0.95 и $0.93 \mathrm{t} / \mathrm{ha}$, respectively, the lowest
- under application of Sekator Turbo, OD (0.1 1/ha) + Zellek-super, EC (1.0 1/ha) - $0.88 \mathrm{t} / \mathrm{ha}$. The application of the tank mixtures of Sekator Turbo, OD (0.1 l/ha) + Quickstep, FEM (0.8 1/ha) on the sowings of the oil flax variety FLIZ helped to receive a yield at the level of the control with manual weeding $-1.29 \mathrm{t} / \mathrm{ha}$, while mixture of Sekator Turbo, OD (0.1 1/ha) + Bagheera, EC $(1.5 \mathrm{l} / \mathrm{ha})$ contributed to obtaining an increase in yield by $0.05 \mathrm{t} / \mathrm{ha}$ compared to the control with manual weeding. The application of the tank mixtures of Sekator Turbo, OD (0.1 l/ha) + Bagheera, EC (1.5 l/ha) and Sekator Turbo, OD (0.1 1/ha) + Miura, EC (1.2 1/ha) on the oil flax variety Nilin led to a significant, by $0.5 \%$, decrease in the oil content of seeds. The tank mixture of Sekator Turbo, OD (0.1 1/ha) + Fuzilad Forte, EC (1.0 1/ha) applied on the variety FLIZ contributed to a significant decrease in the oil content of seeds - by $0.6 \%$. The application of the herbicide mixture of Sekator Turbo, OD $(0.1$ l/ha) + Bagheera, EC (1.5 l/ha) provided the highest oil yield of $0.34 \mathrm{t} / \mathrm{ha}$ for the variety Nilin and $0.54 \mathrm{t} / \mathrm{ha}$ for the variety FLIZ. The tank mixture of Sekator Turbo, OD (0.1 l/ha) + Zellek-super, EC $(1.0 \mathrm{l} / \mathrm{ha})$ on oil flax decreases the productivity of the variety Nilin by $0.11 \mathrm{t} / \mathrm{ha}$, of the variety FLIZ - by $0.15 \mathrm{t} / \mathrm{ha}$, the oil content of seeds of both varieties decreased by $0.6 \%$, while the oil yield by 0.05 and $0.07 \mathrm{t} / \mathrm{ha}$, respectively.

\section{References}

1. K. Pudełko, J. Mańkowski, J. Kołodziej, J. of Natural Fibers, 12, 72 (2015)

2. S. Andruszczak, U. Gawlik-Dziki, P. Kraska, E. Kwiecińska-Poppe, K. Różyło, E. Pałys, Plant, Soil and Envir., 61, 247 (2015)

3. M.E. Kurtenbach, E.N. Johnson, R.H. Gulden, S. Duguid, M. Dyck, C.J. Willenborg, Agron. J., 111(4), 1904 (2019)

4. L.M. Zakharova, Plant protect. and quadrant., 6, 29 (2016)

5. H. Karimmojeni, A. Pirbaloti, P. Kudsk, V. Kanani, A. Ghafori, Agron. J., 3(105), 821 (2013)

6. A. Christos, Int. J. of Agricult. and Biol., 15, 209 (2003)

7. A.P. Avdeenko, Advan. in modern sci., 4, 19 (2015)

8. M.E. Kurtenbach, E.N. Johnson, R.H. Gulden, C.J. Willenborg, Weed Technol., 33(3), 509 (2019)

9. A.S. Bushnev, G.I. Orekhov, S.P. Podlesny, Yu.V. Mamyrko, T.N. Luchkina, Oil Crops, 4, 38 (2020)

10. V.M. Lucomets, A.S. Bushnev, G.I. Orekhov, E3S Web of Conf., 222, 02018 (2020)

11. N.V. Stepanova, D.P. Chirik, S.V. Lyubimov, BarSU Bull., 3, 106 (2015) 